A METHOD OF ESTIMATING FLOOD VOLUMES

IN WESTERN KANSAS

By Charles A. Perry

U.S. GEOLOGICAL SURVEY

Water-Resources Investigations Report 84-4164

Prepared in cooperation with the KANSAS WATER OFFICE

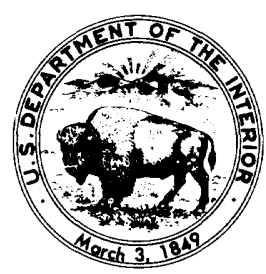

Lawrence, Kansas 
UNITED STATES DEPARTMENT OF THE INTERIOR

\author{
WILLIAM P. CLARK, Secretary \\ GEOLOGICAL SURVEY \\ Dallas L. Peck, Director
}

For additional information write to:

District Chief

U.S. Geological Survey, WRD

1950 Constant Avenue - Campus West University of Kansas

Lawrence, Kansas 66046

[Telephone: (913) 864-4321]
Copies of this report can be purchased from:

Open-File Services Section Western Distribution Branch U.S. Geological Survey Box 25425, Federal Center Denver, Colorado 80225 [Telephone: (303) 236-7476] 


\section{CONTENTS}

Page

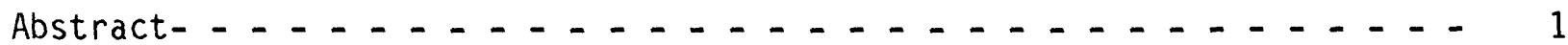

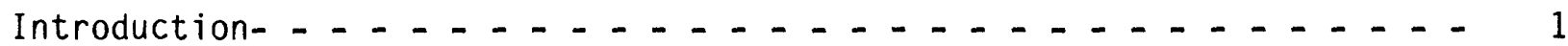

Compilation of data - $\ldots \ldots \ldots$

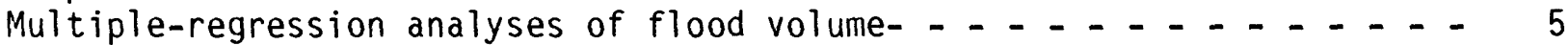

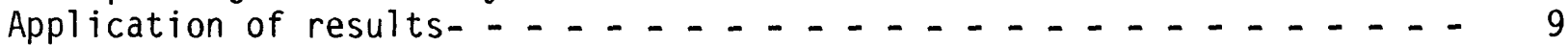

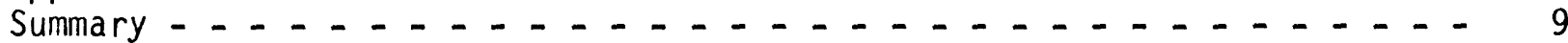

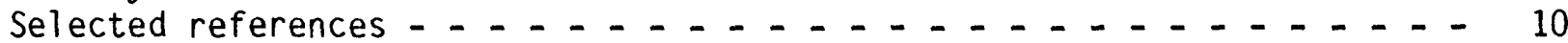

ILLUSTRATIONS

Figure

1. Map showing location of continuous-record streamflowgaging stations used in study $\ldots \ldots$

2. Graph showing flood volume versus peak discharge for basins

smaller than 228 square miles _ . - . - . . . - . -

TABLES

Table

Page

1. Basin characteristics used in multiple-regression analyses

of flood volumes - $\ldots \ldots \ldots$

2. Summary of multiple-regression anaiyses _ _ . $\ldots$

3. Data compilation for basins smaller than 1,503 square miles - - 11

4. Data compilation for basins smaller than 228 square miles - - - 14 
For use by those readers who may prefer to use the International System of Units (SI) rather than inch-pound units, the conversion factors and abbreviations for the terms used in this report are listed below:

\begin{tabular}{lcl}
$\begin{array}{l}\text { Multiply } \\
\text { inch-pound units }\end{array}$ & by & $\begin{array}{l}\text { To obtain } \\
\text { SI units }\end{array}$ \\
\hline inch & $1 / 25.4$ & millimeter \\
foot & 0.3048 & meter \\
mile & 1.609 & kilometer \\
square mile $\left(\mathrm{mi}^{2}\right)$ & 2.590 & square kilometer \\
foot per mile $(\mathrm{ft} / \mathrm{mi})$ & 0.1894 & meter per kilometer \\
inch per hour $(\mathrm{in} / \mathrm{hr})$ & $1 / 25.4$ & millimeter per hour \\
cubic foot per second $\left(\mathrm{ft}^{3} / \mathrm{s}\right)$ & 0.02832 & cubic meter per second \\
acre-foot & 1,233 & cubic meter
\end{tabular}

1 Exact conversion factor. 


\title{
A METHOD OF EVALUATING FLOOD VOLUMES IN WESTERN KANSAS
}

\author{
By Charles A. Perry
}

ABSTRACT

More information on flood volumes in western Kansas is needed to evaluate the availability of surface water in that region. This study developed relationships between flood volume, peak discharge, and basin and climatic characteristics.

Several groups of basins were evaluated according to area and characteristics considered. Multiple-regression analyses revealed a fair relationship between flood volume, peak discharge, channel slope, and storm duration for basins smaller than 1,503 square miles. The equation is

$$
\text { VOL }=0.54 \text { PEAK } 1.17 \text { SLOPE-0.85 DUR } 0.24 \text {. }
$$

A much better relationship for flood volume occurs for basins smaller than 228 square miles when peak discharge, channel slope, and basin area are considered. The standard error of estimate of the multiple-regression equation for basins smaller than 228 square miles was 0.23 logarithm unit $(-41$ and +70 percent $)$, and the correlation coefficient was $R=0.91$. The equation

$$
\text { VOL }=0.48 \text { PEAK } 0.98 \text { SLOPE }-0.74 \text { AREA } 0.30
$$

can be used to compute flood volumes for basins smaller than 228 square miles.

\section{INTRODUCTION}

In western Kansas, there is a need for determining streamflow volumes at locations other than those served by continuous-record streamflow-gaging stations. Streamflow-volume information is needed primarily for small basins because most of the continuous-record stations have been operated only on the major streams in the area. However, many small streams do have creststage-indicator (CSI) gages. This study was conducted in order to develop a relationship between flood volume and peak discharge (incorporating basin and climatic characteristics for individual floods) for continuous-record stations to be used for estimating flood volumes from peak-discharge values for small streams west of $98^{\circ} \mathrm{W}$. longitude. The additional flood-volume information would prove valuable for much-needed studies involving optimum development of water supply, ground-water rechäge, and flood-control reservoirs on small basins. This study was undertaken in cooperation with the Kansas Water office. 
Many factors, such as basin or climatic characteristics, create variations in the relationships of flood volume to peak discharge. Basin shape and channel slope directly affect the time of concentration (the time required for water to flow from the farthest point in the basin to the gaging station); antecedent soil conditions determine the percentage of rainfall that becomes runoff; and timing, intensity, and direction of the storm affect the general shape of the resultant streamflow hydrograph.

\section{COMPILATION OF DATA}

In order to develop relationships between flood volume, peak discharge, and other variables in western Kansas (area generally west of $98^{\circ} \mathrm{W}$. longitude), data from continuous-record streamflow-gaging stations were utilized in the multiple-regression analyses of flood volumes. Data from 1964 to 1981 were examined with two major sets of floods compiled. The first set contained data from floods for basins with drainage areas of up to $1,503 \mathrm{mi}^{2}$ (table 3 at the end of this report). This data set included both basin and climatic characteristics for each flood, most of which occurred during the wetter than normal 1979 water year. Another set of data from 296 floods for basins with drainage areas of up to $228 \mathrm{mi}^{2}$ was compiled excluding the climatic characteristics (table 4 at the end of this report). The location of the 28 continuous-record stations gaging streamflow in the basins studied is shown in figure 1 .

Basin, streamflow, and climatic characteristics were compiled for several floods on all the basins. Basin characteristics included total drainage area (AREA), in square miles, which is important in determining total basin runoff. Channel length (LENTH), in miles, can be an indicator of flood-volume reduction due to the seepage losses along most of the streams in western Kansas. The channel slope (SLOPE), which is the ratio of elevation difference to horizontal distance between points at 10 percent and 85 percent of channel length, controls the time to concentration and, therefore, affects the magnitude of the peak discharge. The U.S. Soil Conservation Service soil infiltration index (SOIL), in inches per hour, can be used to generalize the varied rates of infiltration throughout a basin (Burns and others, 1976). The shape of a basin (SHAPE) affects the shape of the flood hydrograph, with a round basin having a higher peak for uniform rainfall than a long narrow basin with the same area. An index for basin shape (SHAPE) was computed by dividing the square root of AREA by LENTH. The basin characteristics used in the multiple-regression analyses of flood volumes are listed in table 1. 


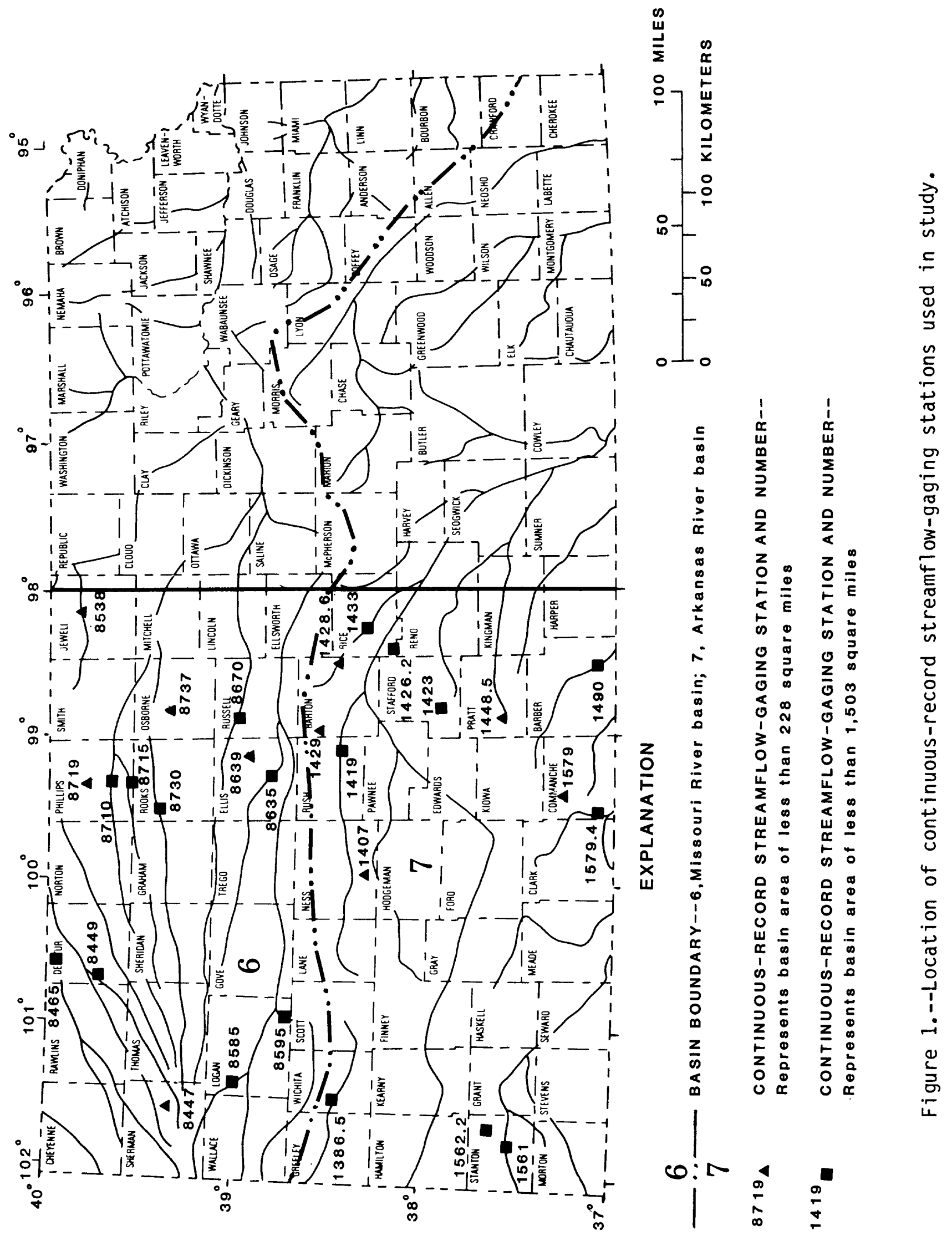


Table 1.--Basin characteristics used in multiple-regression analyses of flood volumes

\begin{tabular}{|c|c|c|c|c|c|}
\hline $\begin{array}{l}\text { Station } \\
\text { number }\end{array}$ & $\begin{array}{l}\text { Drainage } \\
\text { area, } \\
\text { AREA } \\
\text { (square } \\
\text { miles) }\end{array}$ & $\begin{array}{l}\text { Channel } \\
\text { length, } \\
\text { LENTH } \\
\text { (miles) }\end{array}$ & $\begin{array}{l}\text { Channel } \\
\text { slope, } \\
\text { SLOPE } \\
\text { (feet per } \\
\text { mile) }\end{array}$ & $\begin{array}{c}\text { Soil infil- } \\
\text { tration } \\
\text { index, } \\
\text { SoIL } \\
\text { (inches } \\
\text { per hour) }\end{array}$ & $\begin{array}{c}\text { Basin shape } \\
\text { index, } \\
\text { SHAPE } \\
\text { (dimension- } \\
\text { less) }\end{array}$ \\
\hline $\begin{array}{l}06844700 \\
06844900 \\
06846500 \\
06853800 \\
06858500\end{array}$ & $\begin{aligned} & 74.0 \\
& 378 \\
& 1,324 \\
& 227 \\
& 670\end{aligned}$ & $\begin{array}{l}24.6 \\
125 \\
194 \\
37.0 \\
151\end{array}$ & $\begin{array}{c}10.8 \\
7.00 \\
9.60 \\
7.80 \\
9.63\end{array}$ & $\begin{array}{l}3.37 \\
3.37 \\
3.37 \\
3.00 \\
3.30\end{array}$ & $\begin{array}{r}0.35 \\
.16 \\
.19 \\
.41 \\
.17\end{array}$ \\
\hline $\begin{array}{l}06859500 \\
06863500 \\
06863900 \\
06867000 \\
06871000\end{array}$ & $\begin{array}{r}1,460 \\
594 \\
54 \\
1,502 \\
849\end{array}$ & $\begin{array}{l}176 \\
131 \\
16.4 \\
323 \\
162\end{array}$ & $\begin{array}{l}9.00 \\
7.10 \\
8.30 \\
7.80 \\
9.40\end{array}$ & $\begin{array}{l}3.30 \\
2.93 \\
2.93 \\
2.99 \\
3.40\end{array}$ & $\begin{array}{l}.22 \\
.19 \\
.45 \\
.12 \\
.18\end{array}$ \\
\hline $\begin{array}{l}06871500 \\
06871900 \\
06873000 \\
06873700 \\
07138650\end{array}$ & $\begin{array}{r}341 \\
65 \\
1,040 \\
52 \\
750\end{array}$ & $\begin{array}{l}115 \\
21.4 \\
149 \\
13.9 \\
64.5\end{array}$ & $\begin{array}{l}9.10 \\
15.2 \\
10.4 \\
24.0 \\
10.1\end{array}$ & $\begin{array}{l}3.36 \\
3.00 \\
3.37 \\
2.70 \\
3.30\end{array}$ & $\begin{array}{l}.16 \\
.38 \\
.22 \\
.52 \\
.42\end{array}$ \\
\hline $\begin{array}{l}07140700 \\
07141900 \\
07142300 \\
07142620 \\
07142860\end{array}$ & $\begin{array}{c}58.2 \\
1,306 \\
356 \\
1,167 \\
43\end{array}$ & $\begin{array}{c}34.6 \\
130 \\
94.8 \\
174 \\
17.7\end{array}$ & $\begin{array}{l}9.60 \\
7.40 \\
5.00 \\
4.20 \\
6.80\end{array}$ & $\begin{array}{l}3.70 \\
3.16 \\
2.80 \\
4.40 \\
6.70\end{array}$ & $\begin{array}{l}.22 \\
.28 \\
.20 \\
.20 \\
.37\end{array}$ \\
\hline $\begin{array}{l}07142900 \\
71433000 \\
07144850 \\
07149000 \\
07156100\end{array}$ & $\begin{array}{r}61 \\
728 \\
21 \\
903 \\
619\end{array}$ & $\begin{array}{l}19.2 \\
64.1 \\
13.4 \\
95.0 \\
122\end{array}$ & $\begin{array}{c}9.80 \\
3.40 \\
10.6 \\
8.30 \\
16.5\end{array}$ & $\begin{array}{l}3.00 \\
2.66 \\
2.50 \\
2.82 \\
3.00\end{array}$ & $\begin{array}{l}.41 \\
.42 \\
.34 \\
.32 \\
.20\end{array}$ \\
\hline $\begin{array}{l}07156220 \\
07157900 \\
07157940\end{array}$ & $\begin{array}{r}835 \\
39 \\
581\end{array}$ & $\begin{array}{r}121 \\
15.0 \\
69.2\end{array}$ & $\begin{array}{c}14.8 \\
8.60 \\
14.2\end{array}$ & $\begin{array}{l}3.10 \\
3.33 \\
3.30\end{array}$ & $\begin{array}{l}.24 \\
.42 \\
.35\end{array}$ \\
\hline
\end{tabular}


Streamflow characteristics were computed for instantaneous peak discharges (PEAK), in cubic feet per second, and flood volumes (VOL), in acre-feet, from streamflow records for each basin. Single peak flood hydrographs were used in the flood-volume computation by summing discharge from the initial part of the rising limb to the return to base flow on the falling limb. Base flow, if any, was included in computation of flood volume for each case. With nearly all the streams in western Kansas being ephemeral, base flows were usually at or near zero. Base flow was reached when the discharge from 1 hour to the next changed by only 5 percent. Values for PEAK ranged from 3.70 to $8,350 \mathrm{ft}^{3} / \mathrm{s}$. Values for VOL ranged from 0.71 to 19,200 acre-feet.

Climatic characteristics used in the analyses included average basin rainfall (RFD), in inches, and basin antecedent precipitation index (API), in inches. RFD and API values were computed using a contouring and averaging computer program. Data needed for this program are latitude and longitude for points on the basin perimeter and for precipitation stations, and the rainfall for each precipitation station. Using at least three precipitation stations within or near each basin, arrays of rainfall values within the basin were contoured for 5 days before each flood. Average daily basin rainfall values were computed from these arrays. The API (Kohler and Linsley, 1951) was computed from the average daily precipitation values $\left(P_{n}\right)$, using the equation

$$
A P I=\sum_{n=1}^{5} P_{n} K^{n},
$$

where $n$ is the number of days before the flood; and $k$ is the recession coefficient. Due to the semiarid climate and good infiltration properties of most soils, the $K$ for western Kansas was set at 0.80 . Values for RFD ranged from 0.02 to 8.66 inches, and values for API ranged from 0.01 to 4.69 inches.

Maximum 1-hour rainfall intensity (RIN) is in inches per hour, and basin storm duration (DUR) is in hours. Values for RIN ranged from 0.09 to $1.70 \mathrm{in} / \mathrm{hr}$, and values for DUR ranged from 1.0 to 45.0 hours.

\section{MULTIPLE-REGRESSION ANALYSES OF FLOOD VOLUME}

Multiple-regression analyses were conducted with flood volume (VOL) as the dependent variable and peak discharge and basin and climatic characteristics as the independent variables. Step-wise multiple linear-regression equations were computed using the BMD $22 R$ computer program (Dixon, 1970), by adding at each step the variables that reduced the error sum of squares by the greatest amount. The regression model used in these analyses is of the form

$$
V O L=a A^{b} B^{c} c d \text {, }
$$


where $A, B$, and $C$ are basin, streamflow, and climatic characteristics; a is the regression constant; and b, $c$, and d are coefficients defined by regression analysis. Logarithmic transformation of the data was performed to obtain a linear-regression model. By taking logarithms of both sides of equation 2 , the resulting linear equation is obtained

$$
\log Y=\log a+b \log A+c \log B+d \log C \text {. }
$$

The results of the multiple-regression analyses are listed in table 2. The relation between peak discharge and volume is shown in figure 2 .

The significance of each independent variable is indicated by comparing the critical value of the $F$ distribution, which is determined from the number of variables and the number of floods. The multiple-regression program calculates an $F$ number for each variable as it is added to the regression equation. By far the most significant variable in all the analyses was PEAK. The basin characteristics SLOPE, LENTH, SOIL, and AREA and the climatic characteristics RFD and DUR exhibited some significance.

The signs of the linear-regression equations are correct when the physical processes governing flood volume are considered. VOL increases with increasing PEAK. With a negative exponent, a smaller SLOPE results in a larger volume. For a given PEAK, a smaller SLOPE produces a gradual rise and fall of the discharge, resulting in larger volumes; whereas a larger SLOPE produces a steeper rise and fall of the discharge, resulting in smaller volumes. The positive exponents of DUR and AREA mean that longer storms give more flood volume and that a larger basin will produce a larger VOL. Also, longer channel lengths and basins with higher soil infiltration index would result in a larger VOL, as would a storm with a larger RFD.

The low statistical significance of climatic characteristics was assumed to be partly due to the inadequacy of data on small intense storms. Recording precipitation gages are located approximately 30 to 60 miles apart. Nonrecording gages are on the order of 8 to 20 miles apart. The present (1983) precipitation network for western Kansas does not give a good description of high-intensity thunderstorms that are the primary source of flooding for western Kansas.

In each analysis, plots of the residuals from the regression line versus each independent variable were constructed. Inspection of these plots did not reveal any violations of multiple-regression assumptions; the plots indicated that the transformation of data used in the analyses was appropriate. The use of variables in any of the multiple-regression equations outside of the range of those variables used in the analyses is not recommended. 


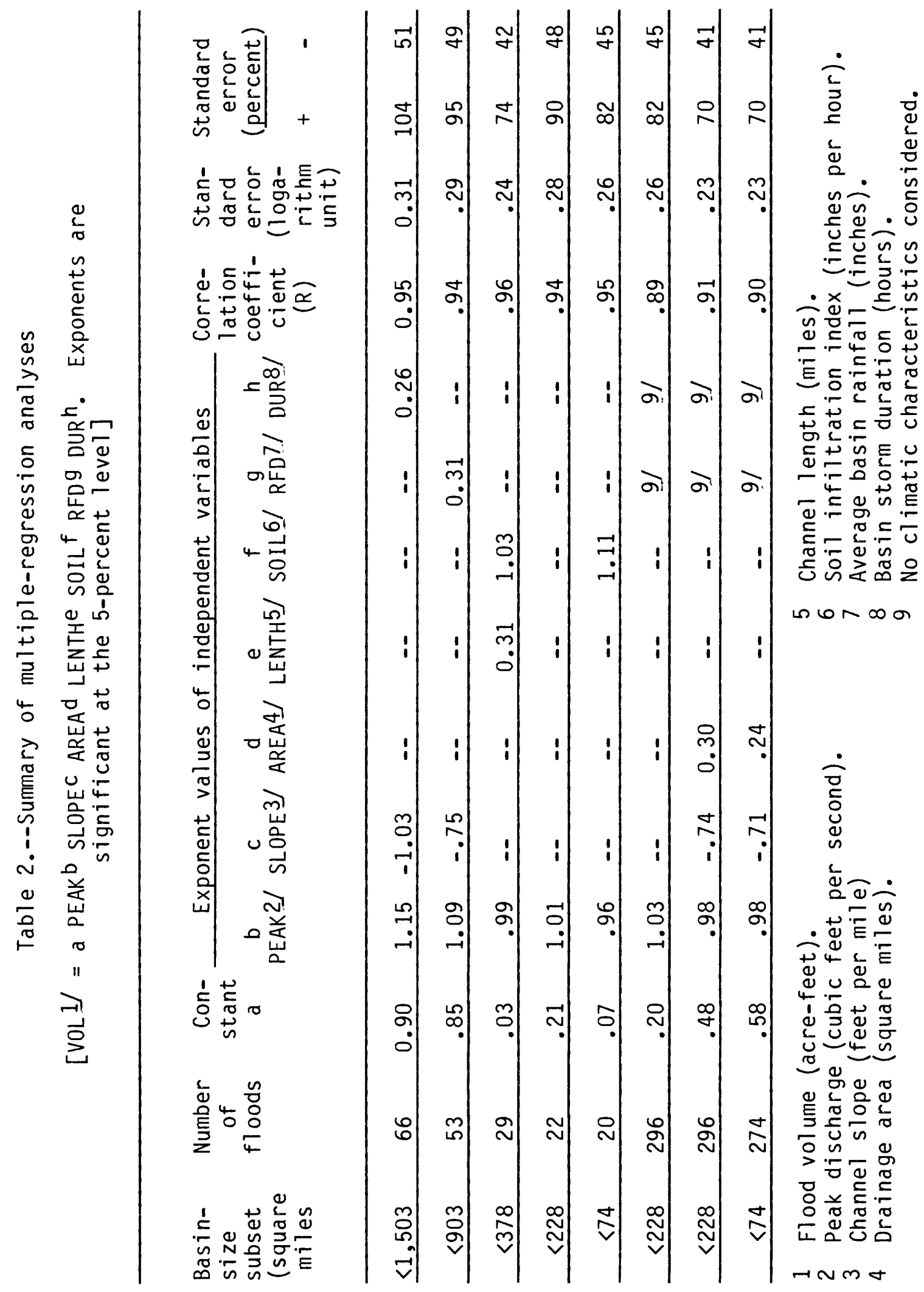




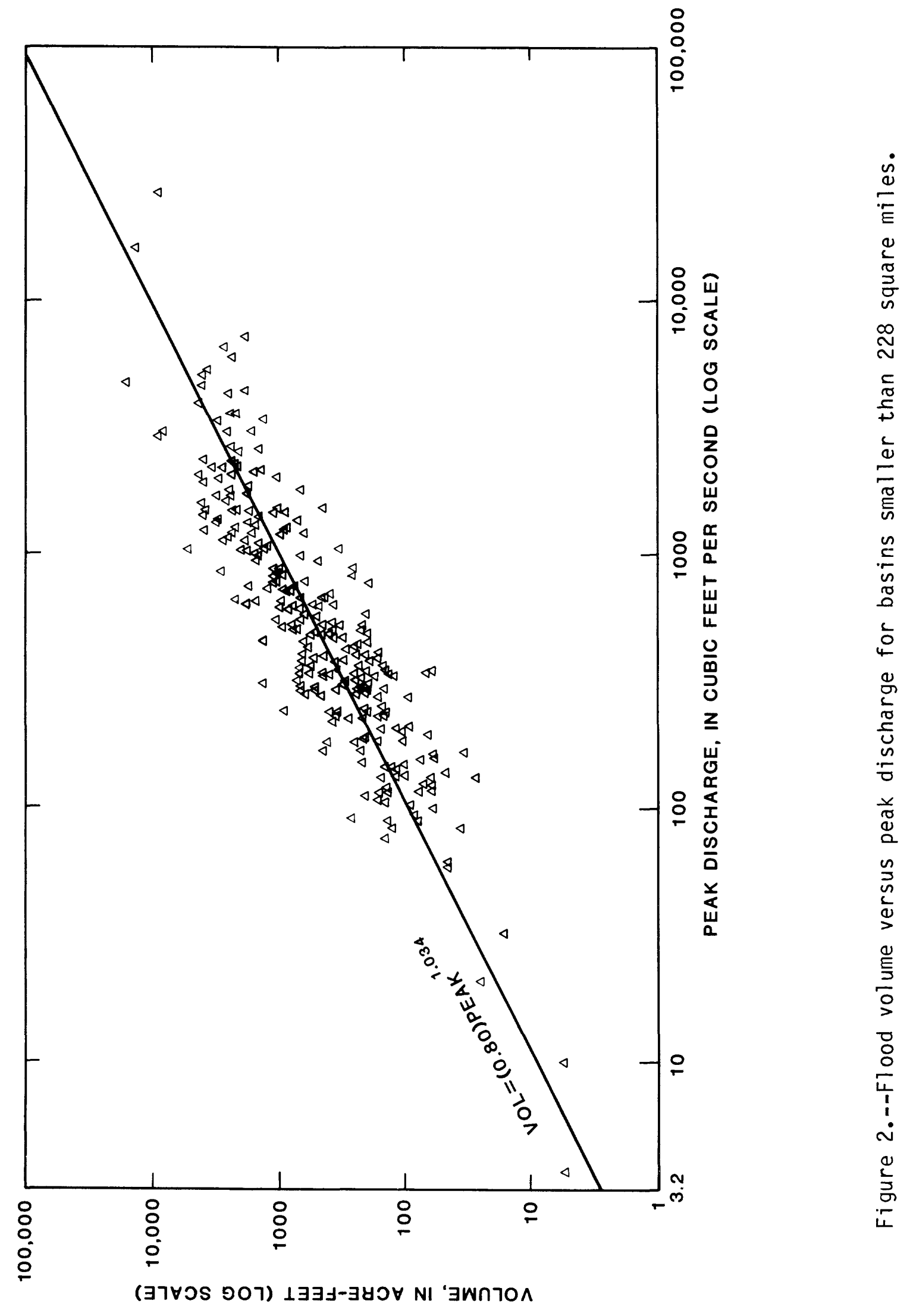


An estimate of the flood volume can be made for basins smaller than 228 $m i^{2}$ in western Kansas using the equation:

$$
\text { VOL }=0.48 \text { PEAK } 0.98 \text { SLOPE-0.74 AREA } 0.30 \text {. }
$$

By using data from CSI gages, which are visited once every 6 weeks, peak discharges from March to October can be converted to flood vol umes and totaled. Significant floods are infrequent during the winter months, so the 8-month totals should be representative of the yearly total. However, precipitation records for any period during which a peak discharge is recorded should be examined in order to determine if there were any lower peak discharges that were erased from the CSI gage. If such periods of flow did occur, an estimate of the peak should be made, and the resulting volume included in the yearly sum. Care should be taken for perennial and intermittent streams to include base flow in the computation of yearly volume total. In Kansas, estimates of flow are made for all CSI gages during March and November. These estimates could be used to approximate base flow, especially if several years of estimates are available.

By using CSI inspection forms, previous yearly totals could be compiled. Statistical frequency analyses of flow volumes then could be performed using the additional volume data from CSI gages.

\section{SUMMARY}

This study has shown that there is a usable relationship between flood volume and peak discharge for streams in western Kansas. Using logarithmic transformation, multiple-regression analyses for two groups of basins revealed that the best peak-volume relationship occurs for basins smaller than 228 $\mathrm{mi}^{2}$. The regression equation included channel slope and area, along with peak discharge as independent variables, and had a correlation coefficient of $R=0.91$ and a standard error of estimate of 0.23 logarithm unit ( -41 and +70 percent). A relationship using peak discharge as the only independent variable had a standard error of 0.26 logarithm unit $(-45$ and +82 percent) and a correlation coefficient of $R=0.89$.

A relationship was defined for basins smaller than $1,503 \mathrm{mi}^{2}$ using peak discharge, channel slope, and basin storm duration as independent variables. However, the standard error of the equation for all basins of less than $1,503 \mathrm{mi}^{2}$ is 0.31 logarithm unit $(-51$ and +104 percent). Had a better network of precipitation stations been available to compute climatic characteristics, the hypothesized relationships may have been substantiated. 
By computing flood volumes for individual peak discharges from CSI gages, additional data are available for the design of culverts, bridges, and flood-detention structures. Also, estimates of the annual volumes can be computed for basins smaller than $228 \mathrm{mi}^{2}$. These computations can be made using either of the equations shown in table 2, depending on available data.

\section{SELECTED REFERENCES}

Burns, C. V., Maddy, D. V., Jordan, P. R., and McNell is, J. M., 1976, Kansas streamflow characteristics--Physical and climatic characteristics along Kansas streams: Kansas Water Resources Board Technical Report No. 13, $41 \mathrm{p}$.

Dixon, W. J., ed., 1970, BMD Biomedical Computer Programs: Berkeley, University of California, p. 233-257d.

Kohler, M. A., and Linsley, R. K., 1951, Predicting the runoff from storm rainfall: U.S. Weather Bureau Research Paper 34, $10 \mathrm{p}$. 


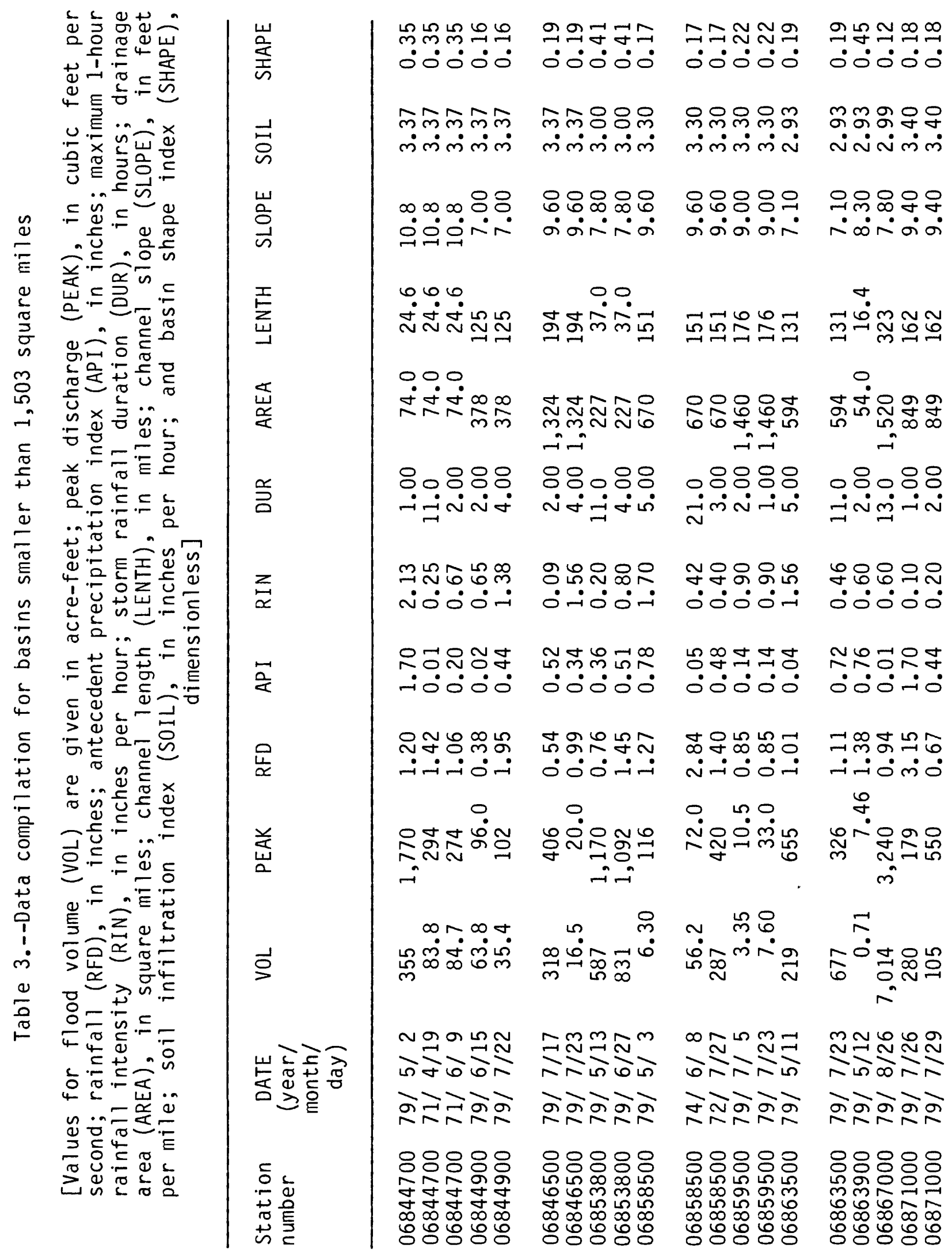




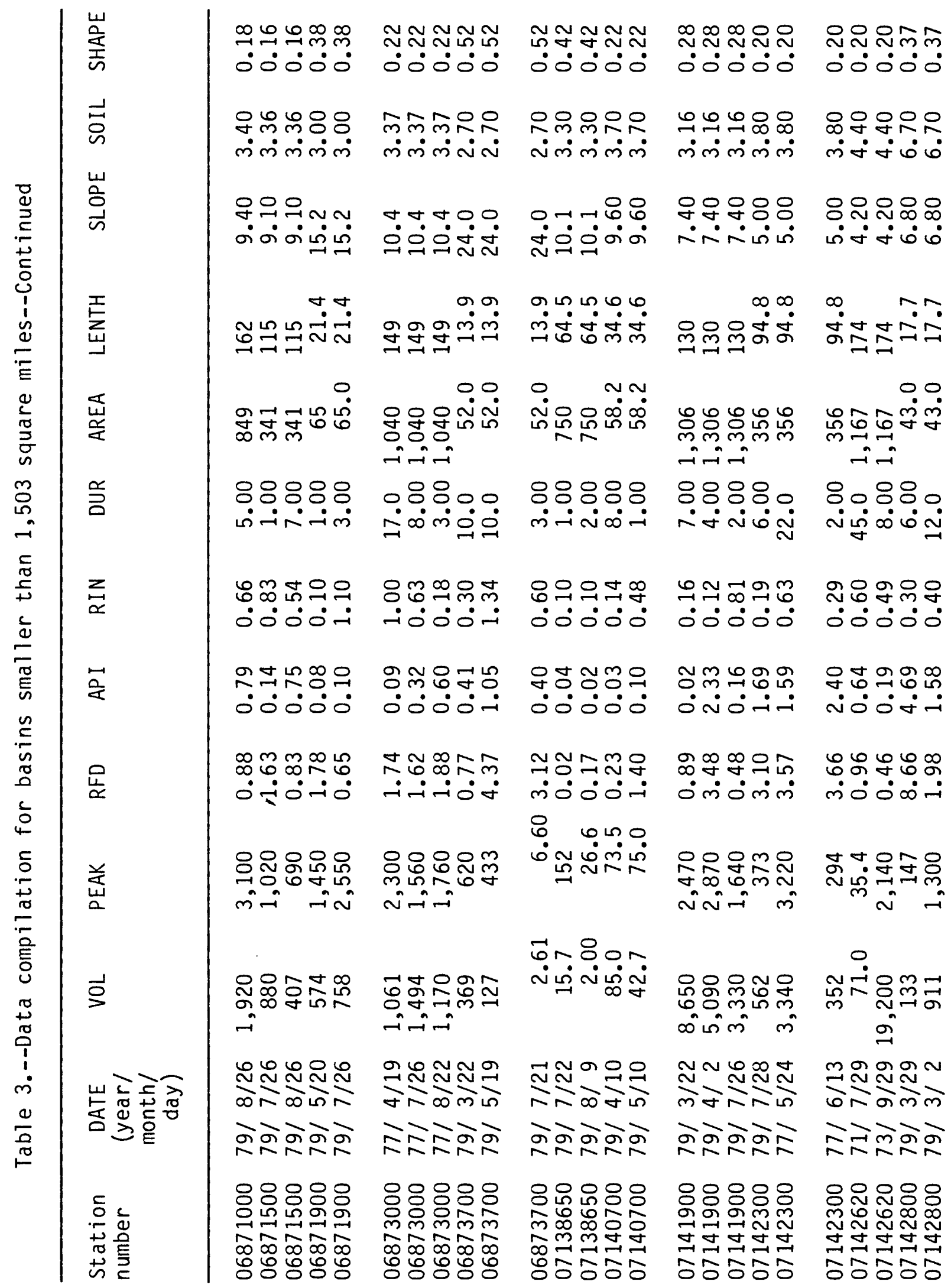




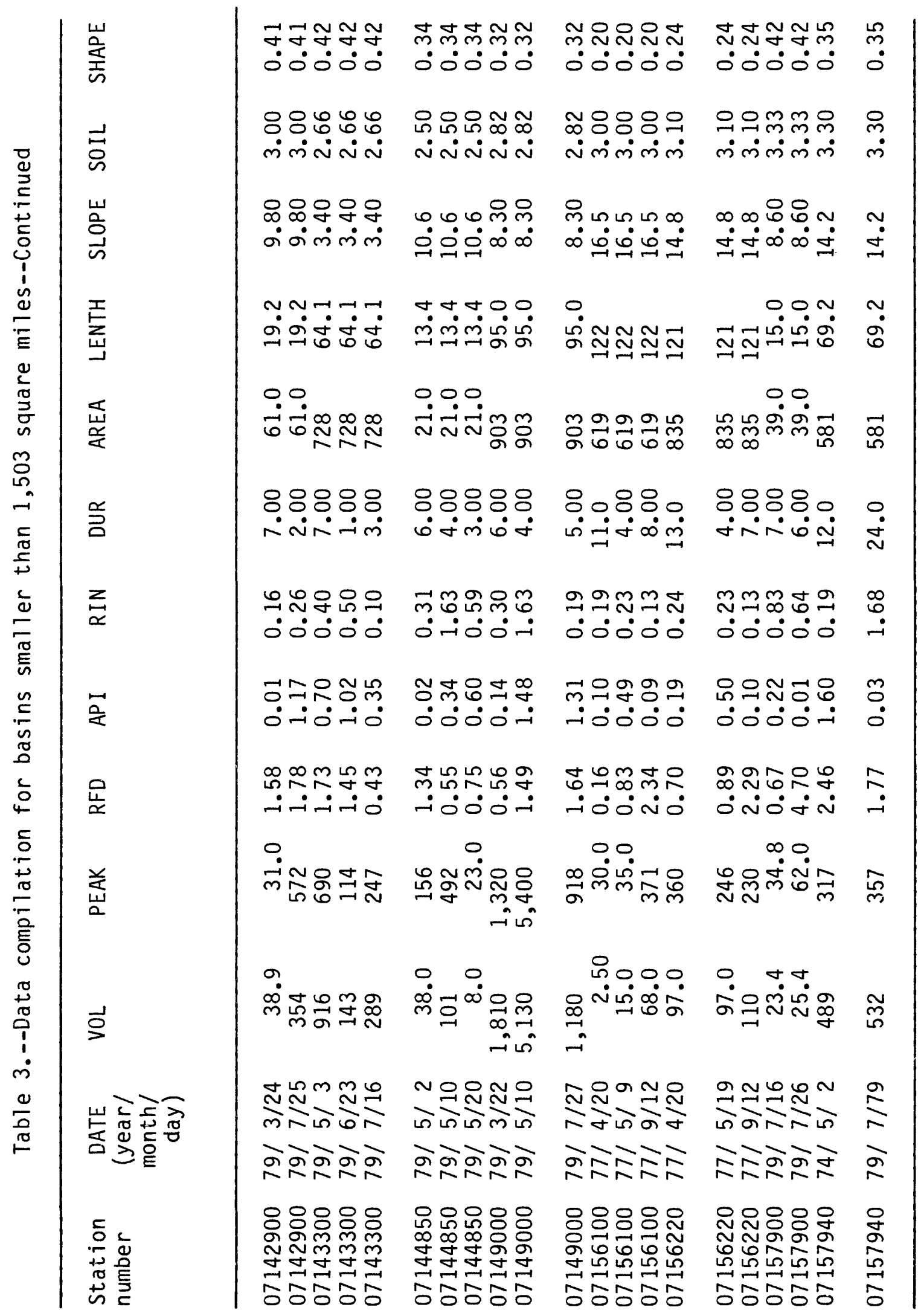




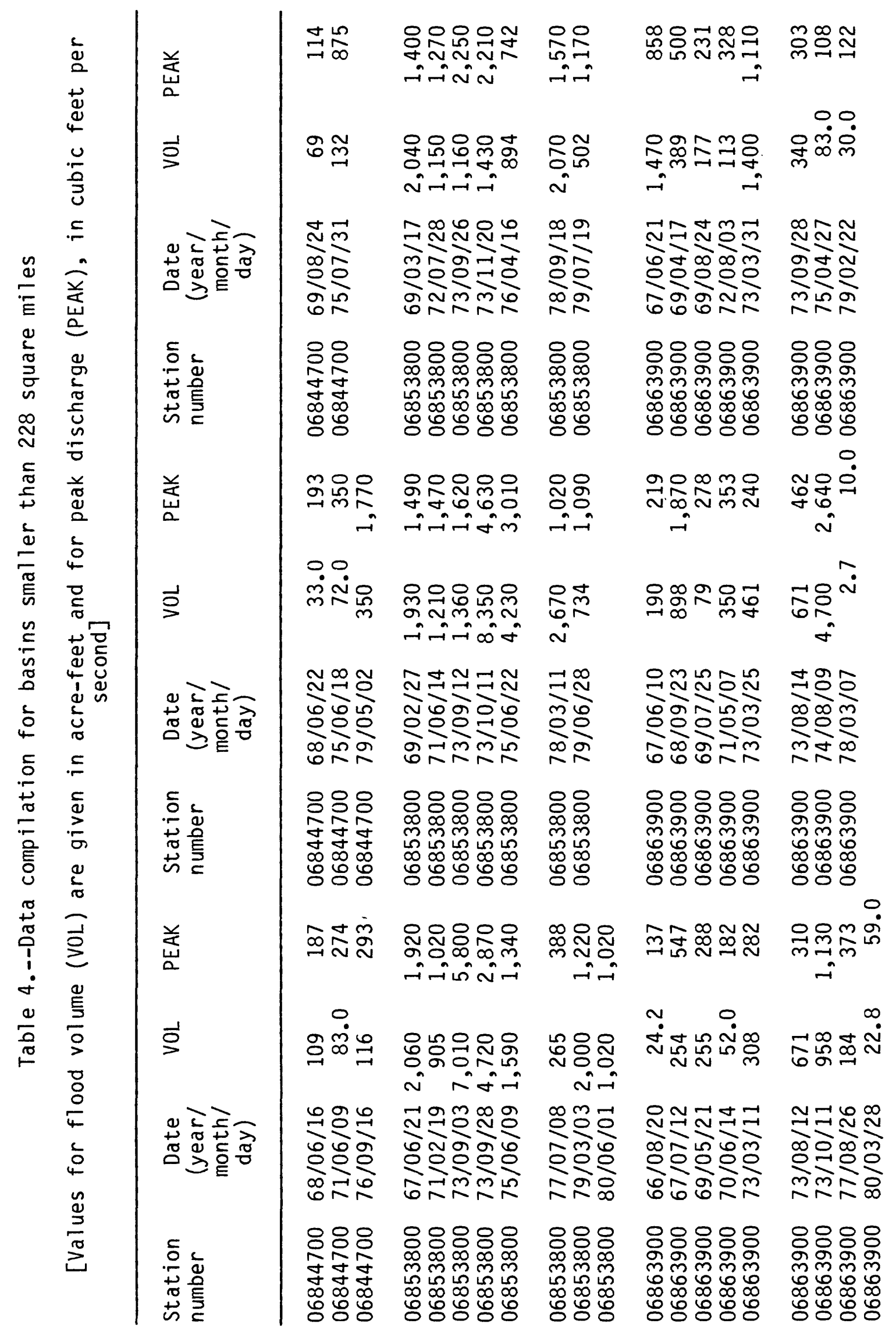




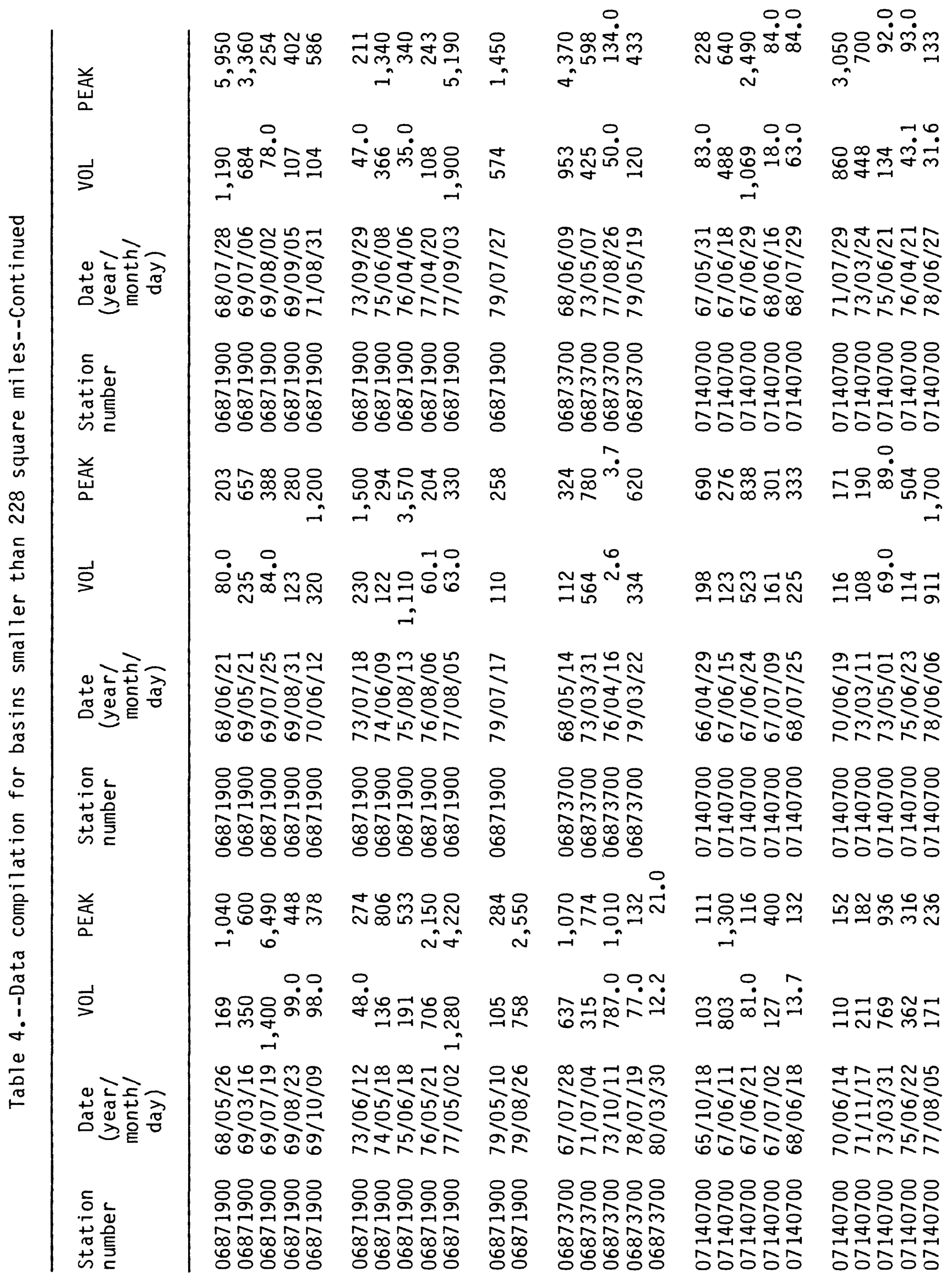




\begin{tabular}{|c|c|c|c|c|c|c|}
\hline 递 & & テ̃ & テન્ન心 & $\begin{array}{l}\text { O } \\
\text { N } \\
\text { - }\end{array}$ & 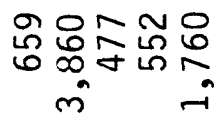 & 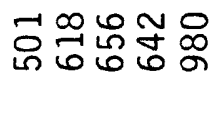 \\
\hline$\vec{\rho}$ & & 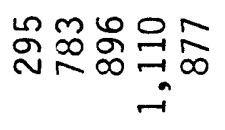 & ๗ָ & ‡ & mo & 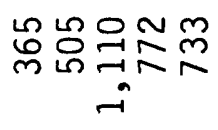 \\
\hline 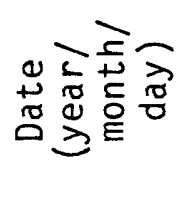 & & 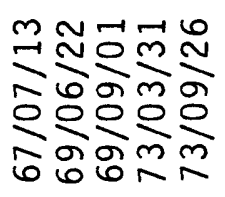 & 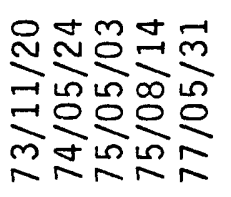 & $\begin{array}{l}\frac{N}{0} \\
\frac{0}{0} \\
\frac{1}{2}\end{array}$ & 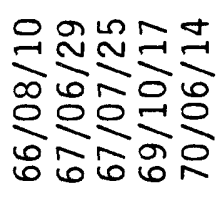 & 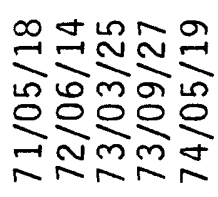 \\
\hline 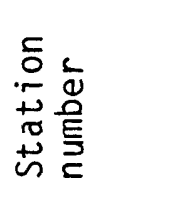 & & 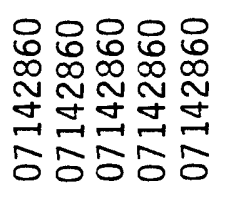 & 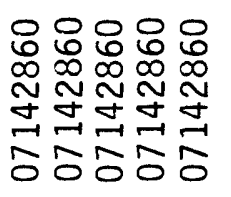 & 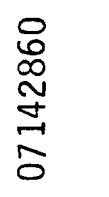 & 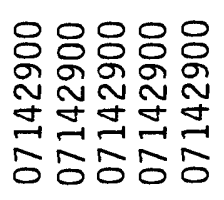 & 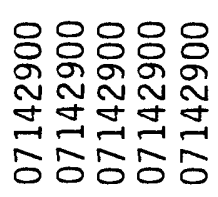 \\
\hline 䛔 & $\underset{\infty}{-1}$ & 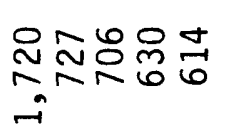 & 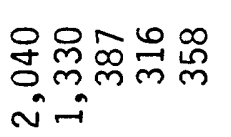 & $\stackrel{\infty}{\stackrel{N}{N}}$ & 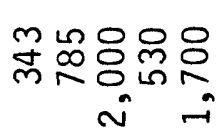 & 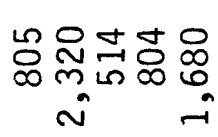 \\
\hline$\stackrel{\vec{\rho}}{\rho}$ & $\stackrel{\sim}{\underset{\sim}{\sim}}$ & 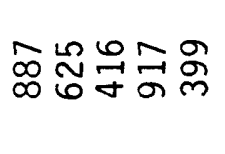 & 芜 & $\stackrel{\infty}{\stackrel{\infty}{\sim}}$ & 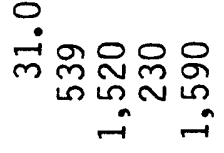 & 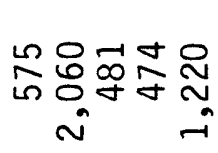 \\
\hline 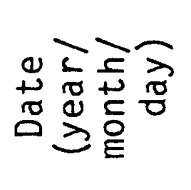 & $\begin{array}{l}\stackrel{0}{1} \\
\vdots \\
\frac{0}{0} \\
\infty\end{array}$ & 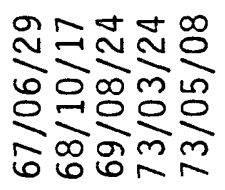 & 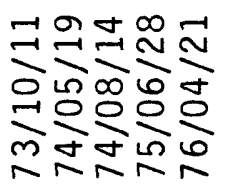 & 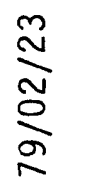 & 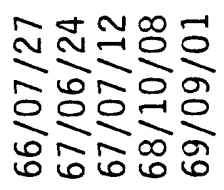 & 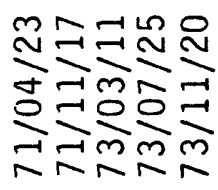 \\
\hline 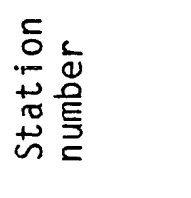 & 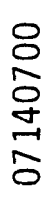 & 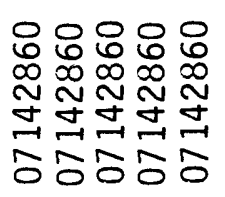 & 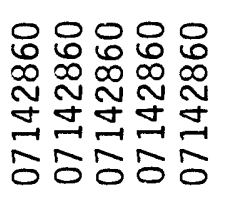 & 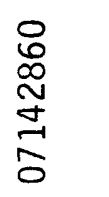 & 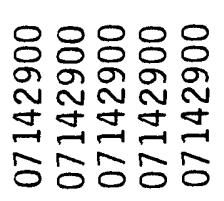 & 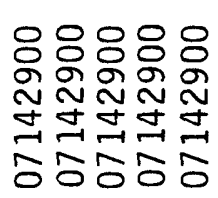 \\
\hline 盖 & م & 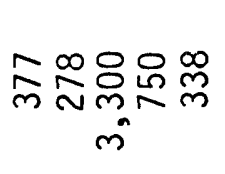 & 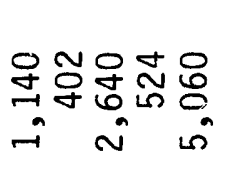 & 웜 & 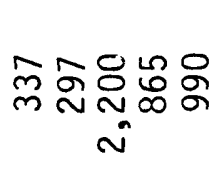 & 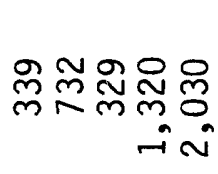 \\
\hline$\vec{\rho}$ & $\begin{array}{l}0 \\
\stackrel{N}{N}\end{array}$ & 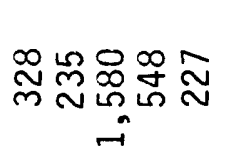 & 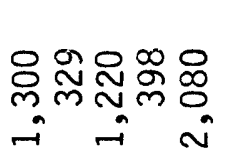 & $\stackrel{\circ}{\stackrel{0}{N}}$ & 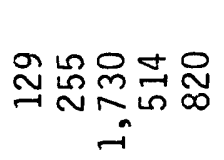 & 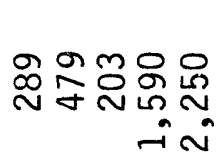 \\
\hline 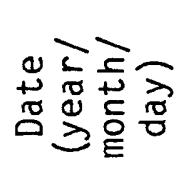 & 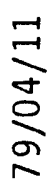 & 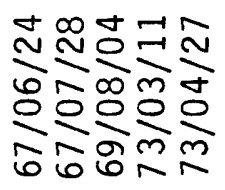 & 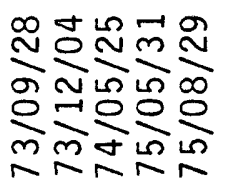 & 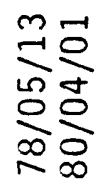 & 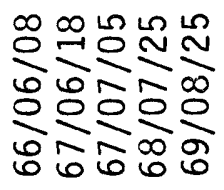 & 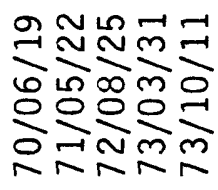 \\
\hline 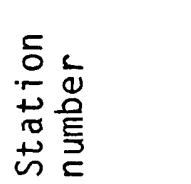 & \begin{tabular}{l}
8 \\
0 \\
○ \\
\multirow{+}{+}{} \\
\multirow{1}{0}{}
\end{tabular} & 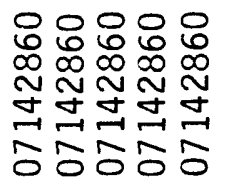 & 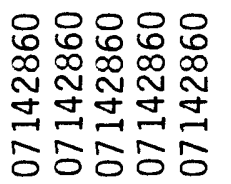 & 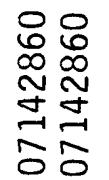 & 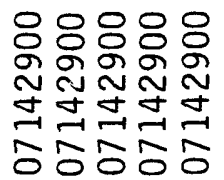 & 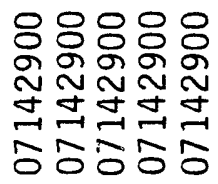 \\
\hline
\end{tabular}




\begin{tabular}{|c|c|c|c|c|c|}
\hline 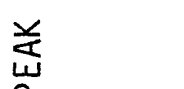 & m & & لْ & 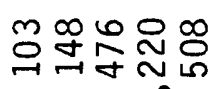 & 유워 \\
\hline$\stackrel{ }{\rho}$ & 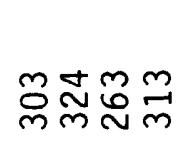 & 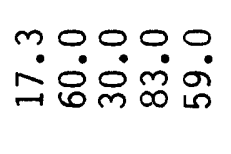 & 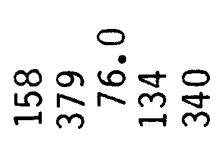 & 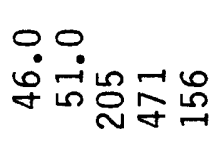 & 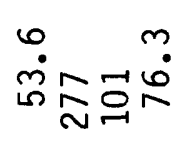 \\
\hline 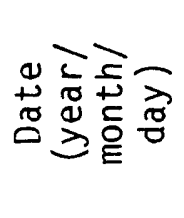 & 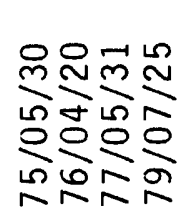 & 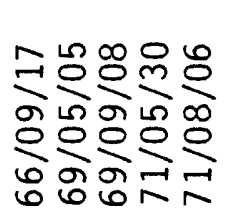 & 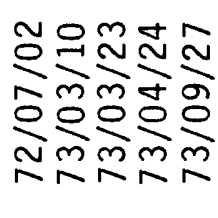 & 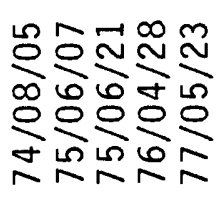 & 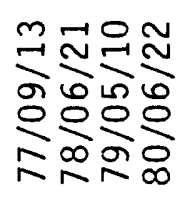 \\
\hline 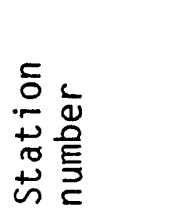 & 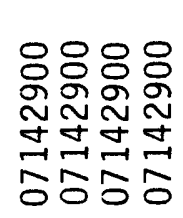 & 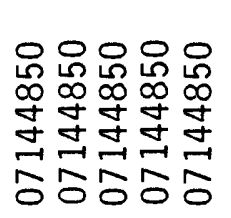 & 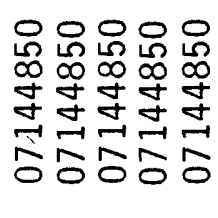 & 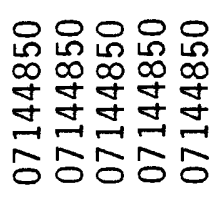 & 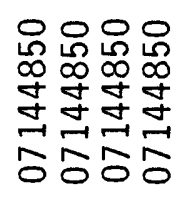 \\
\hline 道 & 윰ำ & 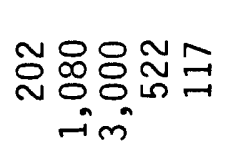 & 过吉ㅇㅇㅁ융요요 & 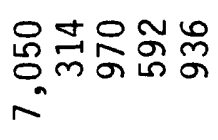 & \begin{tabular}{l}
$O$ \\
\multirow{\sigma}{*}{}
\end{tabular} \\
\hline$\stackrel{\circ}{\rho}$ & 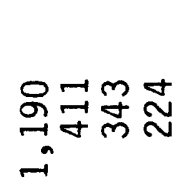 & 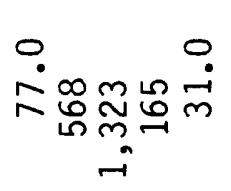 & 용요 & 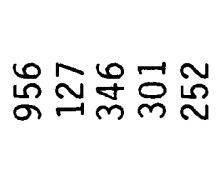 & 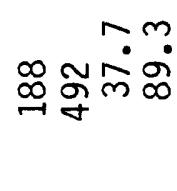 \\
\hline 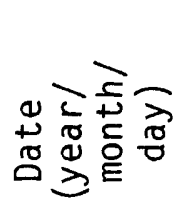 & 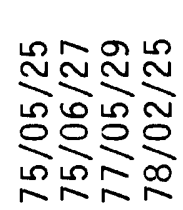 & 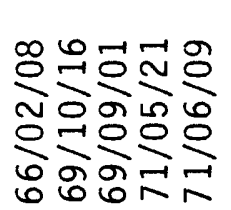 & 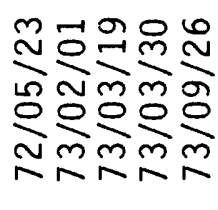 & 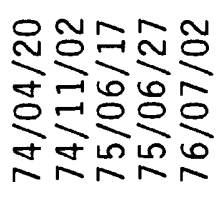 & 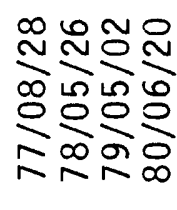 \\
\hline 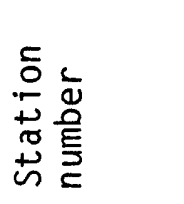 & 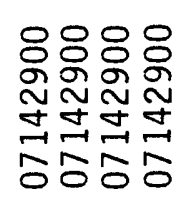 & 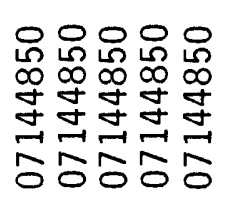 & 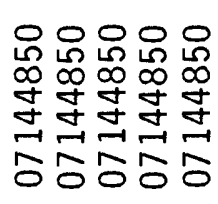 & 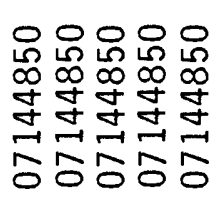 & 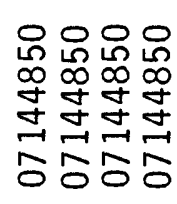 \\
\hline 并 & 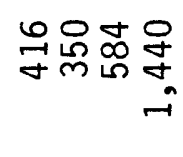 & $\underset{\sim}{\infty} \underset{\sim}{\sim} \underset{\sim}{\sim} \underset{\sim}{\mathbb{N}}$ & 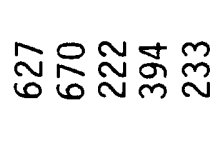 & 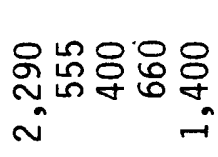 & 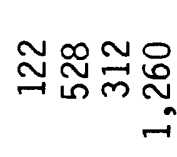 \\
\hline$\stackrel{\vec{\rho}}{\rho}$ & 욜용 & 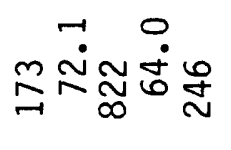 & $\stackrel{\infty}{\infty} \underset{\sim}{\infty} \stackrel{0}{\sim} \underset{\sim}{\sim} \stackrel{ }{\sim}$ & 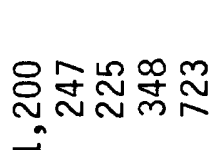 & 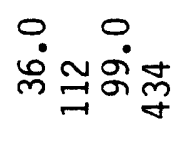 \\
\hline 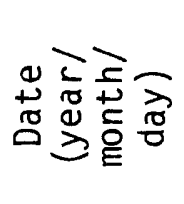 & 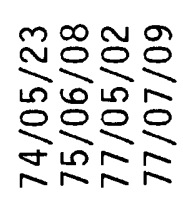 & 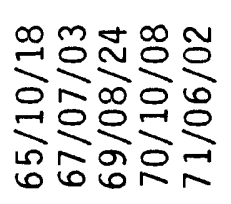 & 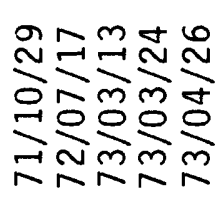 & 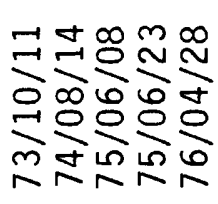 & 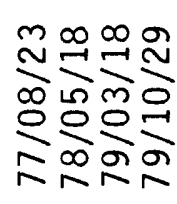 \\
\hline 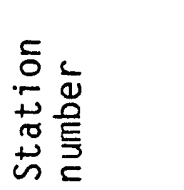 & 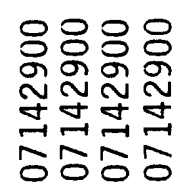 & 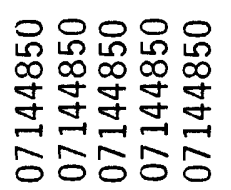 & 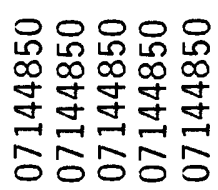 & 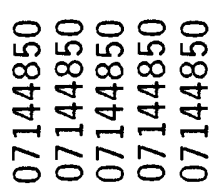 & 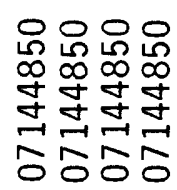 \\
\hline
\end{tabular}




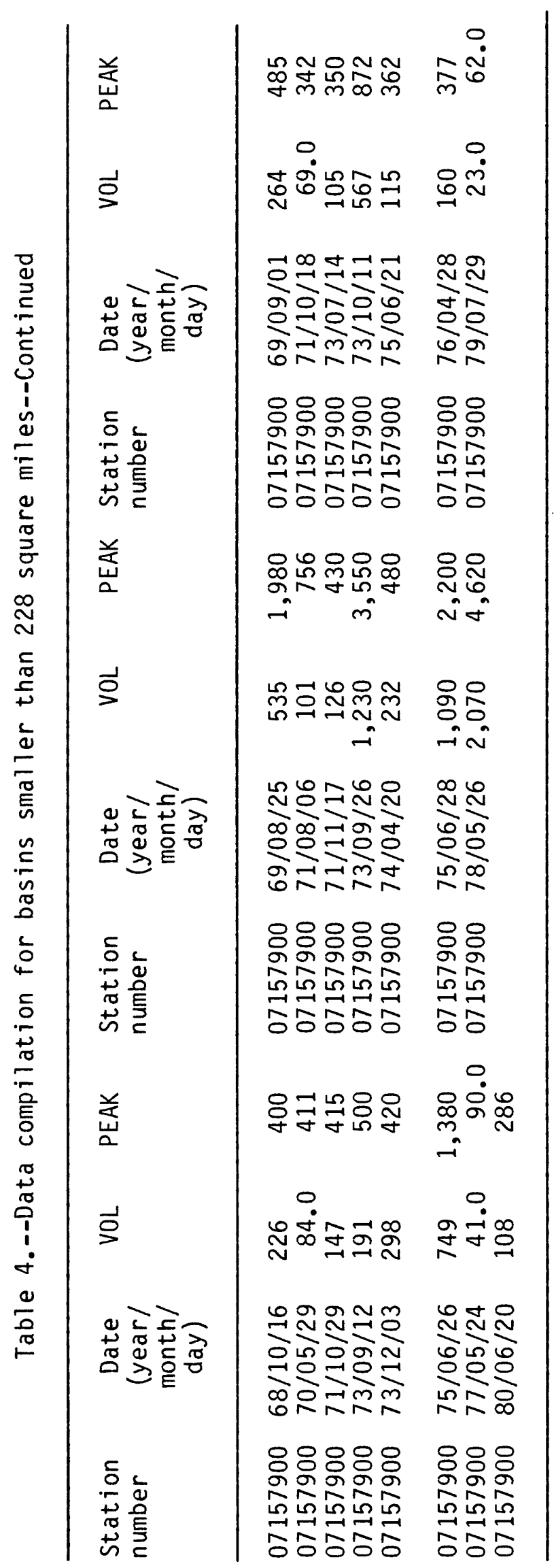

